\title{
Genetic relationships in Saccharum complex germplasm collections based on morphological and molecular markers
}

\author{
Hubungan kekerabatan koleksi plasma nutfah tebu (Saccharum complex) berdasarkan \\ penanda morfologi dan molekuler
}

Wiwit Budi WIDYASARI ${ }^{\left.1)^{*}\right)}$ \& DAMANHURI ${ }^{2)}$

${ }^{1)}$ Indonesian Sugar Research Institute, Jl. Pahlawan 25, Pasuruan, Indonesia

${ }^{2)}$ Faculty of Agriculture, Universitas Brawijaya, Jl. Veteran, Malang, Indonesia

Received 28 January 2021/ Accepted 27 April 2021

\begin{abstract}
Sugarcane has a high degree of heterozygosity and is a cross-pollinator, so information about the genetic relationship between the accessions in germplasm collections is very important for selecting the prospective parent in crossbreeding. This research aims to determine the phylogenetic relationship of 24 Saccharum complex accessions and to verify the grouping of accessions using 37 morphological and three microsatellite molecular markers. Interpretation of morphological and molecular data was obtained from the analysis using the NTYSYpc-2.02i program. The results show that within the 24 accessions analyzed using morphological markers, some accessions did not cluster as the classification at the conservation time. This difference is due to the morphological markers, so the value of genetic similarity among accessions analyzed is increased. In contrast, the grouping of molecular markers shows that each accession was grouped according to the classification at the conservation time. These accessions had a low genetic similarity of 0.20 with a broad genetic distance of 0.80. This broad genetic distance indicates that the twenty-four accessions have a distant genetic relationship with one another, so that the genetic diversity of these accessions is relatively high. The high genetic diversity in germplasm collections improves its potential as a crossing parent to obtain a high heterosis effect.
\end{abstract}

[Keywords: germplasm collection, heterozygosity, heterosis, microsatellites, Saccharum complex]

\footnotetext{
Abstrak

Tebu memiliki derajat heterozigositas yang tinggi dan menyerbuk silang, sehingga informasi tentang hubungan kekerabatan aksesi dalam koleksi plasma nutfah sebagai calon tetua persilangan merupakan hal yang sangat penting. Penelitian ini bertujuan untuk mengetahui hubungan kekerabatan 24 aksesi Saccharum complex dan memverifikasi pengelompokan aksesi tersebut menggunakan 37 penanda morfologi dan 3 penanda molekuler mikrosatelit.

Interpretasi data morfologi dan molekuler diperoleh dari hasil analisis menggunakan program NTYSYpc-2.02i. Hasil penelitian menunjukkan bahwa dari 24 aksesi yang dianalisis menggunakan penanda morfologi, ditemukan beberapa aksesi yang tidak mengelompok sesuai klasifikasi pada saat konservasi. Perbedaan ini disebabkan oleh penanda morfologi, sehingga nilai kemiripan genetik di antara aksesi yang dianalisis meningkat. Sebaliknya, pengelompokan menggunakan penanda molekuler menunjukkan bahwa masingmasing aksesi mengelompok menurut spesies sesuai dengan klasifikasi pada saat konservasi, dan 24 aksesi tersebut memiliki kemiripan genetik rendah yaitu 0,20 dengan jarak genetik sebesar 0,80 . Jarak genetik yang lebar ini menunjukkan bahwa dua puluh empat aksesi tersebut memiliki hubungan genetik yang jauh antara satu dengan yang lainnya, sehingga keragaman genetik aksesi tersebut cukup tinggi. Keragaman genetik yang tinggi pada koleksi plasma nutfah ini meningkatkan potensinya sebagai tetua persilangan untuk mendapatkan efek heterosis yang tinggi.

[Kata kunci: plasma nutfah, heterosigositas, heterosis, mikrosatelit, Saccharum complex]

\section{Introduction}

Sugarcane is one of the most important industrial crops in tropical and subtropical regions because of its ability to store high carbohydrates to produce sugar and biofuel. Sugarcane is an economically important agricultural crop cultivated in over 90 countries, contributing to nearly $80 \%$ of global white sugar production (Raj et al., 2016; Diederichs et al., 2016; Aitken et al., 2018; Pocovi et al., 2020).

Currently, the national sugar production has not been able to meet consumption needs due to several constraints, including low sugarcane and sugar productivity. One of the efforts to overcome this food problem is to intensify breeding activities to obtain superior sugarcane varieties. The assembly of new superior sugarcane varieties is highly dependent on the availability of genetic 
diversity of Saccharum spp.

The genetic diversity of Saccharum spp. is abundant in Indonesia because this country is known as one of the original centers of Saccharum (FAO, 2019). The collection of sugarcane germplasm in the Indonesian Sugar Research Institute (ISRI) began in the 1890 s by Dutch researchers through obtaining accessions of sugarcane from within the Indonesian archipelago and introducing clones from abroad (ISRI, 1997). Lamadji (1994) reported that six expeditions conducted in Indonesia to explore wild sugarcane in Kalimantan, Sulawesi, Maluku, North Sumatera, and Irian Jaya (West Papua) in 1976, 1984, 1985, and 1995. In 2014, the volume of sugarcane germplasm collections managed and conserved by ISRI consisted of 5,294 accessions. The collection consists of a group of native cane (Saccharum officinarum), wild cane (Saccharum spontaneum, Saccharum robustum, Saccharum barberi, Saccharum sinensis, and Saccharum edule), wild relatives of Saccharum (Erianthus and Miscanthus), and Saccharum hybrid (Mirzawan et al., 2014). The modern sugarcane cultivars originated from the Saccharum complex, which consists of two wild Saccharum species ( $S$. spontaneum, and $S$. robustusm), four cultivated species (S. officinarum, S. sinense, S. barberi, and S. edule), and four interrelated genera (Erianthus, Miscanthus, Narenga, and Sclerostachya) (Todd et al., 2014).

Sugarcane is a polyploid plant and has a very complex genome. The Saccharum species present large genomes and variations in the number of chromosomes (Liu et al., 2016; Vieira et al., 2018). The complexity of the Saccharum genome is inherited by modern sugarcane cultivars, in which its levels of ploidy, often aneuploidy, and have a large genome size of about $10 \mathrm{~GB}$ (Vieira et al., 2018; Zhang et al., 2018).

Pollination of sugarcane is both openpollinated and cross-pollinated. Individual plants have a high degree of heterozygosity and the appearance of superior varieties caused by heterosis (Birchler \& Riddle, 2014). With these types of pollinations, sugarcane will produce genetically distinct offspring: between individual offspring, between offspring and their parents, between generations of one offspring and other offspring generations. To maximize the utilization of the sugarcane germplasm collection, it is necessary to evaluate and analyze genetic relationships between the accessions. Genetic relationships between collected germplasm can be evaluated and analyzed through morphological and molecular markers. This will facilitate the selection process of crossing parents and optimize selection procedures (Khan et al., 2009).

An important step before crossing is the selection of the correct parent cross to obtain superior offspring. The strategy for selecting parents can be carried out by characterizing the germplasm with morphological and agronomical markers. However, errors can occur because the vegetative traits are influenced by the environment and often do not reflect the genetic diversity of actual Saccharum accessions (Manechini et al., 2018; Medeiros et al., 2020). Therefore, molecular markers can be used as a complementary tool to characterize morphologically and to identify accessions accurately and reliably so that the combination of accessions as cross parents is suitable for breeding purposes (Marconi et al., 2011; dos Santos et al., 2012; Singh et al., 2018).

Sugarcane breeders and geneticists have discovered the use of numerous DNA markers, including amplified fragment length polymorphisms (AFLP) (Caroll \& Curtis, 1996; D'Hont \& Glaszmann, 2001), restriction fragment length polymorphisms (RFLP) (Burnquist et al., 1995), single nucleotide polymorphism (SNP), simple sequence repeats (SSRs) (Pandey et al., 2011; Hameed et al., 2012), random amplification of polymorphic DNAs (RAPD) (Ullah et al., 2013), inter simple sequence repeat (ISSRs) (Devarumath et al., 2012; Rao et al., 2016; Olieviera et al., 2017), r-DNA-ITS sequence and expressed sequence tagsimple sequence repeat (EST-SSRs) to improve the Saccharum breeding (Ali et al., 2019). Among these molecular markers, SSR (microsatellite) markers have been widely used to study sugarcane genetic diversity, genetic mapping, crosstransferability, paternity analysis, segregation analysis, and marker-assisted selection. SSR primer pairs are considered the most capable marker for plant genetics and breeding programs because of their characteristics that are codominant, multi-allelic nature, and relatively abundant with an excellent genome coverage (Pan, 2010; Costa et al., 2011; dos Santos et al., 2012; Silva et al., 2012; Lopes et al., 2015; Viera et al., 2016; Ali et al., 2019).

This study aims to determine the genetic relationship of 24 clones of Saccharum complex members based on morphological and microsatellite molecular markers and to verify the grouping of 24 Saccharum complex clones based on microsatellite markers.

\section{Materials and Methods}

This research was conducted in the ISRI's germplasm collection station and Biotechnology Laboratory in the 2017/2018 planting season. Twenty-four accessions of ISRI's sugarcane germplasm were members of the Saccharum complex, consisting of S. officinarum, S. barberi, S. sinense, S. robustum, S. spontaneum, Erianthus, Miscanthus, and Saccharum hybrids as an outgroup used in this study (Table 1).

\section{Morphological characterization}

Morphological characterization was carried out directly in the ISRI's germplasm collection station when the plants were \pm seven months old. Each accession was planted in 2 rows, and each row 
consisted of 10 clumps in the germplasm station. Data on measurable morphological characters were recorded in 2017/2018 planting season. Morphological traits were measured on ten random stems for each accession. A total of 37 morphological characters covering three main organs, namely leaves, stems, and buds, were evaluated according to Sastrowijono (1996). Most of these attributes were not subjected to selection in breeding programs; 7 of them related to leaves, 9 of them related to stem traits, while the other seven were subsidiary traits related to buds (Table 2). All measures and observations were carried out in the ISRI's germplasm station and laboratory by means of metric rule and color chart, by the same operators for each attribute, considered stable enough observations for the different genotypes.

\section{Molecular characterization}

Deoxy Nucleic Acid (DNA) extraction was carried out using the CIMMYT Laboratory method. This method followed Saghai-Maroof et al. (1984) with minor modification by reducing one cycle for precipitation. DNA was precipitated without overnight incubation at room temperature but incubated for 60 minutes at $-20^{\circ} \mathrm{C}$. This method had been used in the molecular research of sugarcane by Alix et al. (1998). The molecular characterization in this study used three types of microsatellite primers, as shown in Table 3 .

The PCR results were visualized by electrophoresis on $1.5 \%$ agarose gel with $100 \mathrm{bp}$ DNA ladder (Fermentas) and $1 \mathrm{~kb}$ DNA ladder (Promega) as DNA markers. The gel was visualized using Ethidium Bromide by incubated for 45 minutes in a dark room and observed with a UV transilluminator and documented with Doc XR Gel (Biorad).

\section{Data analysis and interpretation}

Morphological character data were transferred to the binary data format with number 1 for the character that appeared (present) and number 0 for the character that did not appear (absent). Likewise, molecular data in the form of amplified DNA bands were interpreted as qualitative data. Then the data were presented in the form of binary data as seen from the presence and absence of DNA bands. The presence of DNA bands was marked with the number 1 , while the absence of DNA bands as indicated by the number 0 in the same array. The interpretation of this data referred to the research of Pan et al. (2003).The DNA bands generated through microsatellite markers were marked with numbers 1 and 0 and presented in the form of binary data.

Table 1. Sugarcane germplasm accessions were used in the study Tabel 1. Aksesi plasma nutfah tebu yang digunakan dalam penelitian

\begin{tabular}{|c|c|c|c|c|}
\hline No. & $\begin{array}{l}\text { Accession name/ } \\
\text { Nama aksesi }\end{array}$ & $\begin{array}{l}\text { Species/ } \\
\text { Spesies }\end{array}$ & $\begin{array}{l}\text { Locations/ } \\
\text { Lokasi }\end{array}$ & $\begin{array}{l}\text { Years of expedition/ } \\
\text { Tahun exepedisi }\end{array}$ \\
\hline 1. & IS 76-202 & Erianthus & Sulawesi & 1976 \\
\hline 2. & IS $76-205$ & Erianthus & Sulawesi & 1976 \\
\hline 3. & IK $76-149$ & Erianthus & Kalimantan & 1976 \\
\hline 4. & IK $76-150$ & Erianthus & Kalimantan & 1976 \\
\hline 5. & IK $76-153$ & Erianthus & Kalimantan & 1976 \\
\hline 6. & IJ 76-374 & Erianthus & Irian Jaya & 1976 \\
\hline 7. & IJ 76- 375 & Erianthus & Irian Jaya & 1976 \\
\hline 8. & IJ 76-370 & Erianthus & Irian Jaya & 1976 \\
\hline 9. & IJ $76-348$ & Erianthus & Irian Jaya & 1976 \\
\hline 10. & IJ 76-396 & Erianthus & Irian Jaya & 1976 \\
\hline 11. & M 442-51 & Saccharum spp. Hybrids & B37172 X M213-40 & $*)$ \\
\hline 12. & PS-862 & Saccharum spp. Hybrids & POJ 2722 (polycross) & $*)$ \\
\hline 13. & TD 50 & S.officinarum & Jawa & $*)$ \\
\hline 14. & TD 53 & S.officinarum & Jawa & $*)$ \\
\hline 15. & 15 OC 18 & S.sinense & $*)$ & 1915 \\
\hline 16. & 15 OC 19 & S.sinense & $*)$ & 1915 \\
\hline 17. & IK76-36 & S.spontaneum & Kalimantan & 1976 \\
\hline 18. & IK 76-41 & S.spontaneum & Kalimantan & 1976 \\
\hline 19. & IS $76-175$ & Miscanthus & Sulawesi & 1976 \\
\hline 20. & IS $76-181$ & Miscanthus & Sulawesi & 1976 \\
\hline 21. & IJ 76-412 & S.robustum & Irian Jaya & 1976 \\
\hline 22. & IJ $76-415$ & S.robustum & Irian Jaya & 1976 \\
\hline 23. & X OC 55 & S.barberi & *) & 1921 \\
\hline 24. & X OC 56 & S.barberi & $*)$ & 1925 \\
\hline
\end{tabular}

Notes : *) unknown

Keterangan : *) tidak diketahui 
Table 2. Qualitative and quantitative morphological markers are assessed in 24 accessions of the Saccharum complex. Abbreviation, morphological markers/characters , and descriptors were indicated for each observed variable

Tabel 2. Penanda morfologi kualitatif dan kuantitatif yang digunakan untuk menilai 24 aksesi Saccharum complex. Singkatan, penanda/karakter morfologi dan descriptor ditunjukkan untuk setiap variabel yang diamati

\begin{tabular}{|c|c|c|}
\hline $\begin{array}{l}\text { Abbreviation } \\
\text { Singkatan }\end{array}$ & $\begin{array}{l}\text { Morphological markers/characters } \\
\text { Penanda/karakter morfologi }\end{array}$ & $\begin{array}{l}\text { Descriptors } \\
\text { Deskriptor }\end{array}$ \\
\hline D1 & $\begin{array}{l}\text { Curved leaf blade of the plant } \\
\text { Lengkung helai daun }\end{array}$ & $\begin{array}{l}\text { A. Upright (Tegak) } \\
\text { B. C u r v e }<1 / 2(\text { Melengkung }<1 / 2) \\
\text { C. Curve } \geq 1 / 2(\text { Melengkung } \geq 1 / 2)\end{array}$ \\
\hline D2 & $\begin{array}{l}\text { Leaves color } \\
\text { Warna daun }\end{array}$ & $\begin{array}{l}\text { A. Green (Hijau) } \\
\text { B. Dark green }(\text { Hijau tua }) \\
\text { C. Yellowish green }(\text { Hijau kekuningan })\end{array}$ \\
\hline D3 & $\begin{array}{l}\text { The width of leaf blade } \\
\text { Lebar daun }\end{array}$ & $\begin{array}{l}\text { A. Narrow }(<4 \mathrm{~cm})(\text { Sempit }(<4 \mathrm{~cm}) \\
\text { B. Medium }(4-6 \mathrm{~cm})(\text { Sedang } 4-6 \mathrm{~cm}) \\
\text { C. Width }(>6 \mathrm{~cm})(\text { Lebar }(>6 \mathrm{~cm})\end{array}$ \\
\hline D4 & $\begin{array}{l}\text { Auricles position } \\
\text { Kedudukan telinga daun }\end{array}$ & $\begin{array}{l}\text { A. U pright }(\text { Te g a k) } \\
\text { B. Oblique (Serong) } \\
\text { C. Absent (Tidak bertelinga) }\end{array}$ \\
\hline D5 & $\begin{array}{l}\text { The height of auricles } \\
\text { Tinggi telinga daun }\end{array}$ & $\begin{array}{l}\text { A. } 1 \mathrm{~cm} \\
\text { B. }>1-<3 \mathrm{~cm} \\
\text { C. } \geq 3 \mathrm{~cm} \\
\text { D. Absent (Tidak bertelinga) }\end{array}$ \\
\hline D6 & $\begin{array}{l}\text { Dewlap color } \\
\text { Warna sendi segitiga daun }\end{array}$ & $\begin{array}{l}\text { A. Yellowish green (Hijau kekuningan) } \\
\text { B. Brownish green (Hijau kecoklatan) } \\
\text { C. Green brownish yellow (Hijau kuning kecoklatan) } \\
\text { D. Green (Hijau) } \\
\text { E. Others (Lainnya) }\end{array}$ \\
\hline P1 & $\begin{array}{l}\text { Hairy ligule } \\
\text { Bulu bidang punggung }\end{array}$ & $\begin{array}{l}\text { A. Absent (Tidak ada) } \\
\text { B. Rarely (Jarang) } \\
\text { C. Heavy (Lebat) }\end{array}$ \\
\hline $\mathrm{P} 2$ & $\begin{array}{l}\text { The length of the hairy ligule } \\
\text { Panjang bulu bidang punggung }\end{array}$ & $\begin{array}{l}\text { A. Not reaching the top of the ligule (Tidak mencapai } \\
\text { puncak bidang punggung) } \\
\text { B. Nearly reaching ( } \leq 1 \mathrm{~cm} \text { ) the top ligule (Hampir } \\
\text { mencapai }(\leq 1 \mathrm{~cm} \text { ) puncak bidang punggung) } \\
\text { C. Reaching the top of the ligule (Mencapai puncak } \\
\text { bidang punggung) } \\
\text { D. Absent (tidak ada) }\end{array}$ \\
\hline P3 & $\begin{array}{l}\text { Hairy ligule width } \\
\text { Lebar bulu bidang punggung }\end{array}$ & $\begin{array}{l}\text { A. Narrow }(<1 / 4 \text { ligule) (Sempit }(<1 / 4 \text { lebar bidang } \\
\text { punggung) } \\
\text { B. W i d t } \mathrm{h}(\geq 1 / 4 \text { ligule) }(\text { Lebar }(\geq 1 / 4 \quad \text { lebar bidang } \\
\quad \text { punggung) } \\
\text { C. Absent }(\text { Tidak ada })\end{array}$ \\
\hline P4 & $\begin{array}{l}\text { Hairy ligule position } \\
\text { Kedudukan bulu bidang } \\
\text { punggung }\end{array}$ & $\begin{array}{l}\text { A. Fall down (Rebah) } \\
\text { B. L e a n i g ( Condong) } \\
\text { C. Up rig h t (Tegak) } \\
\text { D. Absent (Tidak ada) }\end{array}$ \\
\hline P5 & $\begin{array}{l}\text { Leaf midrib wax } \\
\text { Lapisan lilin pelepah }\end{array}$ & $\begin{array}{l}\text { A.Little (Sedikit) } \\
\text { B. Medium (Sedang) } \\
\text { C. A lot (Banyak) }\end{array}$ \\
\hline P6 & $\begin{array}{l}\text { Removing leaf midribs } \\
\text { Sifat lepas pelepah }\end{array}$ & $\begin{array}{l}\text { A. Hard (Sulit) } \\
\text { B. Rather easy (Agak mudah) } \\
\text { C. E a s y }(M u d a h)\end{array}$ \\
\hline P7 & $\begin{array}{l}\text { Leaf midrib color } \\
\text { Warna pelepah }\end{array}$ & $\begin{array}{l}\text { A. Dark green (Hijau tua) } \\
\text { B. Yellowish green (Hijau kekuningan) } \\
\text { C. Green purplish yellow (Hijau kuning keunguan) } \\
\text { D. Reddish yellow green (Hijau kuning kemerahan) } \\
\text { E. Others (Lainnya) }\end{array}$ \\
\hline
\end{tabular}


Table 2. (Continue)

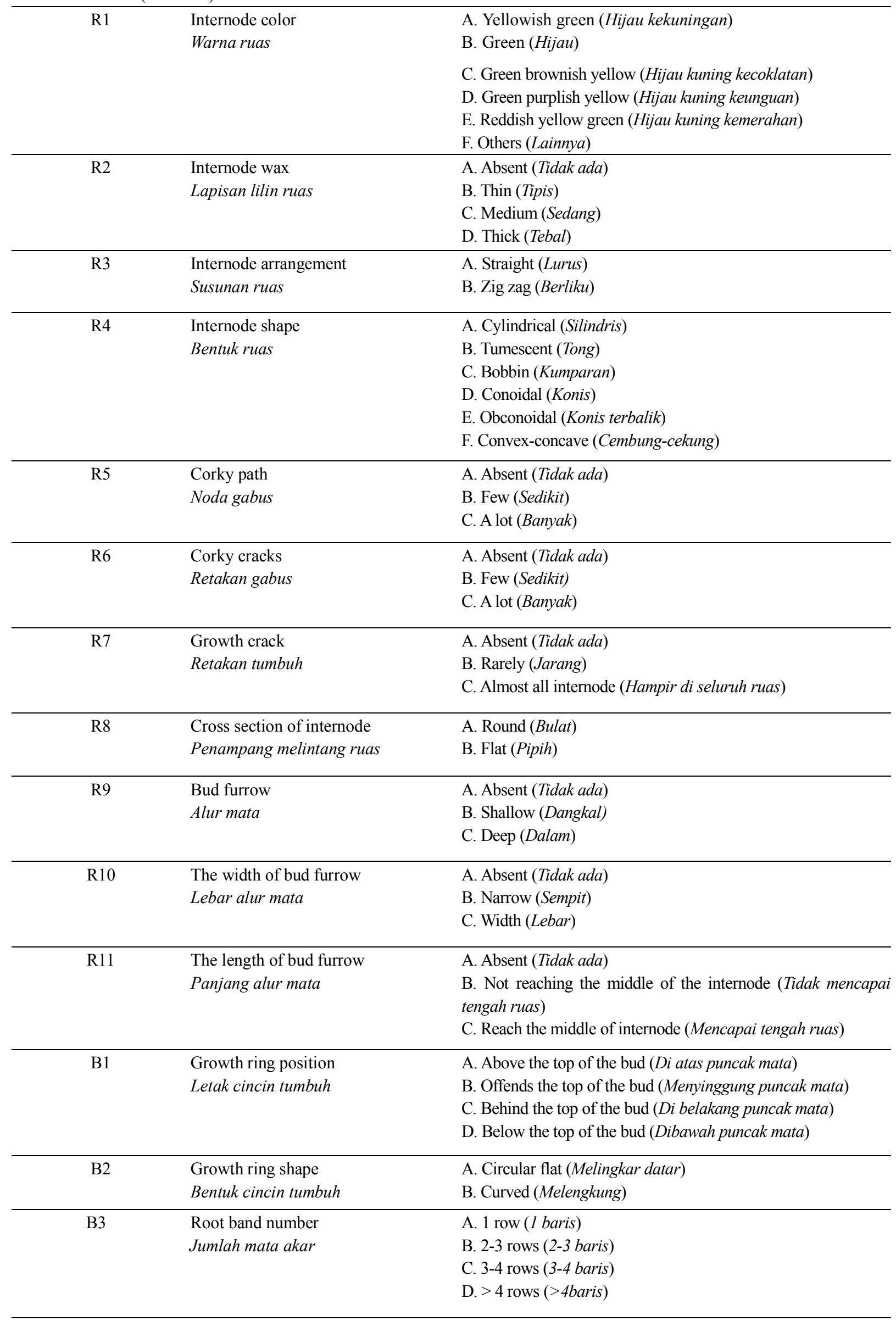


Table 2 (Continue)

\begin{tabular}{|c|c|c|}
\hline B4 & $\begin{array}{l}\text { Node shape } \\
\text { Bentuk buku ruas }\end{array}$ & $\begin{array}{l}\text { A. Cylindrical (Silindris) } \\
\text { B. Conoidal (Konis) } \\
\text { C. Obconoidal (Konis terbalik) } \\
\text { D. Tumescent (Tong) } \\
\text { E. Bobbin (Kumparan) }\end{array}$ \\
\hline M1 & $\begin{array}{l}\text { Bud position } \\
\text { Kedudukan mata }\end{array}$ & $\begin{array}{l}\text { A. On the former leaf midrib (Pada bekas pangkal pelepah daun) } \\
\text { B. Above the former leaf midrib (Di atas bekas pangkal pelepah } \\
\text { daun) }\end{array}$ \\
\hline M2 & $\begin{array}{l}\text { Bud shape } \\
\text { Bentuk mata }\end{array}$ & $\begin{array}{l}\text { A. Round (Bulat) } \\
\text { B. Oval (Oval) } \\
\text { C. Ovate (Bulat telur) } \\
\text { D. Rhomboid (Bulat telur terballik) } \\
\text { E. Triangular (Segitiga) }\end{array}$ \\
\hline M3 & $\begin{array}{l}\text { The widest part of the bud } \\
\text { Bagian terlebar mata }\end{array}$ & $\begin{array}{l}\text { A. Under the middle of the bud (Di bawah tengah-tengah mata) } \\
\text { B. In the middle of the bud (Pada tengah-tengah mata) } \\
\text { C. Above the middle of the bud (Di atas tengah-tengah mata) }\end{array}$ \\
\hline M4 & $\begin{array}{l}\text { Bud wing size } \\
\text { Ukuran sayap mata }\end{array}$ & $\begin{array}{l}\text { A. Equal width (Sama lebar) } \\
\text { B. Narrow base (Basis sempit) } \\
\text { C. Base width (Basis lebar) }\end{array}$ \\
\hline M5 & $\begin{array}{l}\text { Growth center } \\
\text { Pusat tumbuh }\end{array}$ & $\begin{array}{l}\text { A. Under the middle of the bud (Di bawah tengah mata) } \\
\text { B. In the middle of the bud (Pada tengah mata) } \\
\text { C. Above the middle of the bud (Di atas tengah mata) } \\
\text { D. At the top of the bud (Di puncak mata) }\end{array}$ \\
\hline M6 & $\begin{array}{l}\text { The hair on the edge of the bud } \\
\text { basal } \\
\text { Rambut tepi basal mata }\end{array}$ & $\begin{array}{l}\text { A. Absent (Tidak ada) } \\
\text { B. Present }(A d a)\end{array}$ \\
\hline M7 & $\begin{array}{l}\text { Hair on top of bud } \\
\text { Rambut jambul mata }\end{array}$ & $\begin{array}{l}\text { A. Absent (Tidak ada) } \\
\text { B. Present }(A d a)\end{array}$ \\
\hline M8 & $\begin{array}{l}\text { Bud size } \\
\text { Ukuran mata }\end{array}$ & $\begin{array}{l}\text { A. Small }(\text { Kecil }) \\
\text { B. Medium }(\text { Sedang }) \\
\text { C. Big }(\text { Besar })\end{array}$ \\
\hline M9 & $\begin{array}{l}\text { The edge of the bud wing } \\
\text { Tepi sayap mata }\end{array}$ & $\begin{array}{l}\text { A. Flat (Rata) } \\
\text { B. Jagged (Bergerigi) } \\
\text { C. Notched peaks (Puncak berlekuk) }\end{array}$ \\
\hline
\end{tabular}

Table 3. Three types of microsatellite primers were used in this study

Tabel 3. Tiga jenis primer mikrosatelit yang digunakan dalam penelitian

\begin{tabular}{llc}
\hline No. & \multicolumn{1}{c}{ Primers/ Primer } & SSR Sequences/Sekuen SSR \\
\hline 1. & MCSA053C10 & (CAG)5 \\
2. & SMC1047HA & (GA)26 \\
3. & mSSCIR5 & (GGC) 9 \\
\hline
\end{tabular}

Furthermore, binary data were also used to determine the value of genetic similarity and arrange genetic relationship trees. The genetic similarity coefficient used for morphological markers was the Simple Matching similarity coefficient (Sneath \& Sokal, 1973). For molecular data, relationships between pairwise accessions were estimated using the Jaccard Coefficient (Cordeiro et al., 2003; Pan et al., 2003; Pocovi et al., 2020).

In this study, the accessions were then clustered by the Unweighted Pair-Group Method with
Arithmetic Averages (UPGMA) cluster method with the Numerical Taxonomy and Multivariate Analysis System (NTSYSPC-2.02i) program (Schenk et al., 2004; Alwala et al., 2006; Parida et al., 2008; Pocovi et al., 2020). Cophenetics value matrices of the UPGMA clustering were used to test the goodness-of-fit of the clustering to the similarity matrix on which it was based by means of computing the product-moment correlation (r) with 1000 permutations (Mantel, 1967). 


\section{Results and Discussion}

\section{Morphological characterization}

The 24 accessions of the Saccharum complex analyzed, based on 37 morphological characters, showed similarities and differences in morphological descriptors. The most similar morphological characters in the 24 accessions were on the leaves, internodes, and buds. On the leaves, similar traits are curved leaf blade, leaf color, auricle position, auricle height, dewlap color, the length of the hairy ligule, the width of the hairy ligule, hairy ligule position, midrib wax, removing leaf midribs, and leaf midrib color. On the internode, similar characters are internode color, internode shape, corky path, corky cracks, growth cracks, and the cross-section of the internode. In the bud, similar characters are bud furrow, bud furrow width, bud furrow length, growth ring position, growth ring shape, bud position, bud shape, the widest part of the bud, growth center, the hair on the edge of the bud basal, hair on top of bud, bud size and the edge of the bud wing.

The accessions within the Saccharum species show several similar morphological characters. Two S. officinarum accessions (TD50 and TD53) have 27 characters in common, two $S$. sinense accessions (15OC18 and 15OC19) have 31 characters in common, two $S$. spontaneum accessions (IK76-36 and IK76-41) have 33 characters in similarity, two $S$. barberi accessions (XOC55 and XOC56) and two $S$. robustum accessions (IJ76-412 and IJ76-415) each have 17 characters in common.

The morphological characters distinguished between the accessions analyzed from the genus Erianthus and Saccharum in this study were located in the internode and bud. The distinctive character included the arrangement of internode (Erianthus: straight, Saccharum: zigzag); cross- section of internode (Erianthus: flat, Saccharum: round); the number of root buds (Erianthus: 1 row, Saccharum: 2-3 rows); and the widest part of the bud (Erianthus: under the middle of the bud, Saccharum in the middle of the bud). This resembles the observations reported by Amalraj and Balasundaram (2006), concerning the difference between Saccharum and Erianthus, among others, on the number of root buds. Erianthus had only 1 row of root bud number, whereas in Saccharum the number of root buds was two rows or more.

Qualitative data of morphological characterization were transformed into binary data to make a relationship dendrogram. Figure 1 shows that the phylogenetic relationship among 24 accessions of the Saccharum complex is divided into two large clusters at the similarity value of $0.66(66 \%)$. The first cluster consists of 22 accessions and the second cluster consists of 2 accessions, namely PS 862 (Saccharum hybrid) and XOC55 (Miscanthus).

The greatest value of genetic similarity based on morphological characters was between IK 76375 and IK $76-205$ of 0.9683 (97\%). The genetic distance between the two accessions was 0.0317 , which means that the phylogenetic relationship between the two accessions is close. This was because IK 76-375 and IK 76-205 are both of the Erianthus genus originating from Kalimantan. In contrast, the lowest genetic similarity values were PS 862 and IJ 76-396 at 0.5714 (57\%), and the genetic distance was 0.4286 . PS 862 was a commercial sugarcane variety from ISRI's breeding program (Saccharum hybrid), while IJ 76-396 was Erianthus from Papua (Indonesia) so that the genetic relationship between the two accessions was farther than the other accessions.

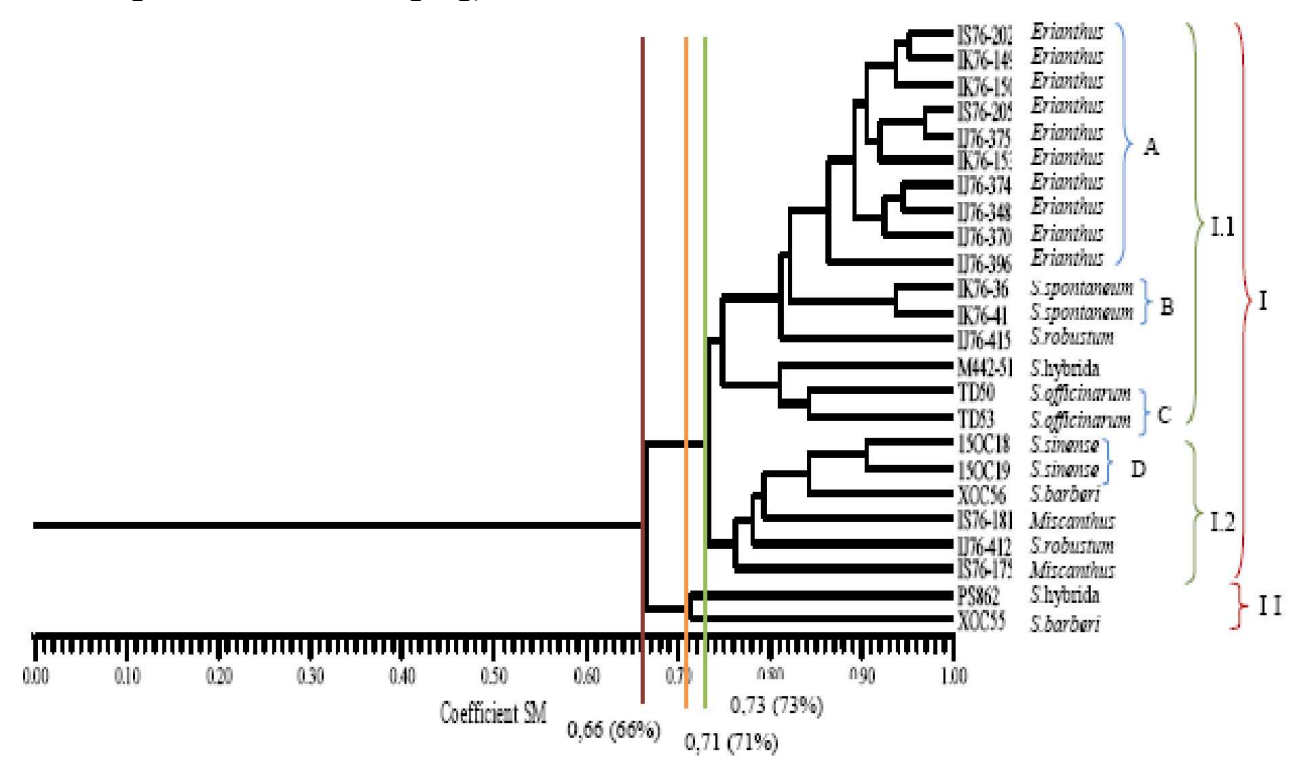

Figure 1. The genetic relationship of 24 Saccharum complex accessions constructed with Simple Matching Coefficients based on morphological markers

Gambar 1. Hubungan kekerabatan 24 aksesi Saccharum complex yang dikonstruksi dengan koefisien Simple Matching berdasarkan penanda morfologi 
The clustering based on morphological markers (Figure 1) mainly corresponded to the classification at the conservation time. However, there were several accessions of Saccharum barberi, namely XOC 56 and XOC 55, which were distinct from one another, and accessions of Saccharum robustum, namely IJ76-412 and IJ76415 , which were not in the same group. Likewise, M 442-51 and PS 862 were not included in the Saccharum hybrids cluster. Meanwhile, the accessions of Erianthus, $S$. spontaneum, $S$. officinarum, and $S$. sinensis were clustered according to the classification at the time of conservation.

\section{Molecular characterization}

The results of DNA amplification of the three microsatellite primers are shown in Figure 2-4. The three primers produced 90 DNA bands with varying sizes of base pairs. In this study, the DNA bands analyzed were DNA bands that could be seen clearly, regardless of the difference in intensity (thickness or thinness of the DNA bands).

Figure 2 shows that the microsatellite amplification of 24 accessions using mSSCIR5 primer resulted in 44 polymorphic DNA bands, with sizes ranging from $83 \mathrm{bp}$ to $1600 \mathrm{bp}$.
Meanwhile, Figure 3 shows that the SMC1047HA primer amplified the DNA of 24 Saccharum complex accessions to produce 22 bands. The sizes of the DNA bands ranged from $76 \mathrm{bp}$ to $1642 \mathrm{bp}$. In Figure 4, it can be seen that the MSCA053C10 primer produced 24 DNA bands with sizes ranging from $98 \mathrm{bp}$ to $950 \mathrm{bp}$.

Three pairs of microsatellite primers produced 90 DNA bands in the range of $76 \mathrm{bp}-1642 \mathrm{bp}$. The data generated from the three microsatellite primers were transformed into binary data to form a dendrogram for genetic relationships using the NTSYSpc-2.02i program. Jaccard's genetic similarity coefficient used a scale of $0.00-1.00$. The value of 1.00 indicated $100 \%$ similarity, which meant that the value of genetic distance or dissimilarity was 0.00 (Indah et al., 2008; Pocovi et al., 2020).

The dendrogram constructed from three microsatellite primers shows in Figure 5 that the 24 accessions of the Saccharum complex were divided into two large clusters at a similarity value of 0.02. Large cluster I at a similarity value of 0.19 formed two subclusters, namely I.1 and I.2. Subcluster I.1 was divided into four sub-clusters, namely: (A) S. spontaneum cluster, (B). $S$. offcinarum cluster, (C). Erianthus cluster from Kalimantan and Sulawesi; (D) S. sinense cluster.
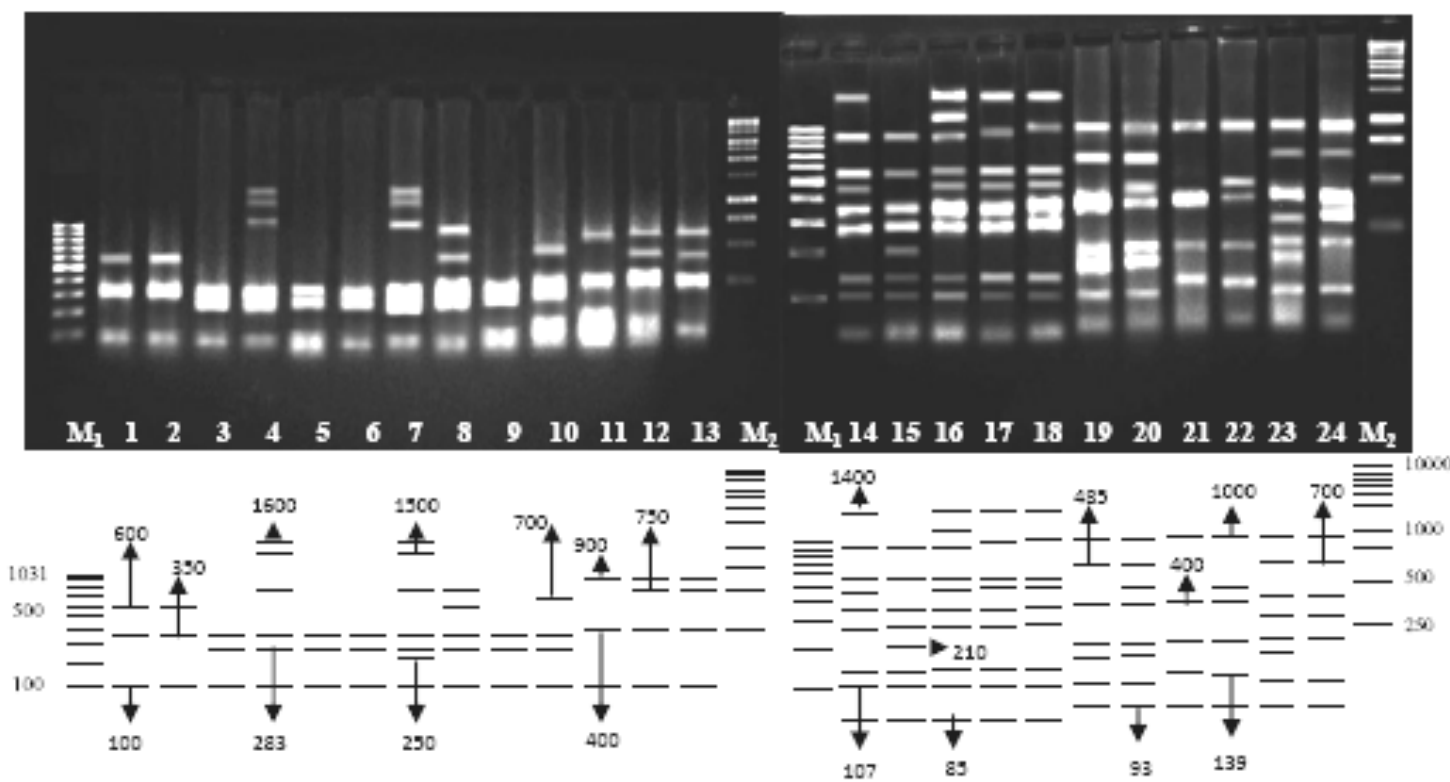

Figure 2. Electrophoregram of 24 accessions DNA amplification results using mSSCIR5 microsatellite Gambar 2. Elektroforegram hasil amplifikasi DNA 24 aksesi menggunakan mikrosatelit mSSCIR5

Remark: IS 76-202, 2. IS 76-205, 3. IK 76-149, 4. IK 76-150, 5. IK 76-153, 6. IJ 76-374, 7. IJ 76- 375, 8. IJ 76-370, 9. IJ 76-348, 10. IJ 76-396, 11. M 442-51, 12. PS-862, 13. TD 50, 14. TD 53, 15. 15 OC 18, 16.15 OC 19, 17. IK76-36, 18. IK76-41, 19. IS 76-175, 20. IS 76-181, 21. IJ 76-412, 22. IJ 76-415, 23. X OC 55, 24. X OC 56, M1. Marker 100 bp and M2. Marker $1 \mathrm{~kb}$.

Keterangan: IS 76-202, 2. IS 76-205, 3. IK 76-149, 4. IK 76-150, 5. IK 76-153, 6. IJ 76-374, 7. IJ 76- 375, 8. IJ 76-370, 9. IJ 76-348, 10. IJ 76-396, 11. M 442-51, 12. PS-862, 13. TD 50, 14. TD 53, 15. 15 OC 18, 16. 15 OC 19, 17. IK76-36, 18. IK76-41, 19. IS $76-175,20$. IS 76-181, 21. IJ 76-412, 22. IJ 76-415, 23. X OC 55, 24. X OC 56, M1. Marker 100 bp and M2. Marker $1 \mathrm{~kb}$ 


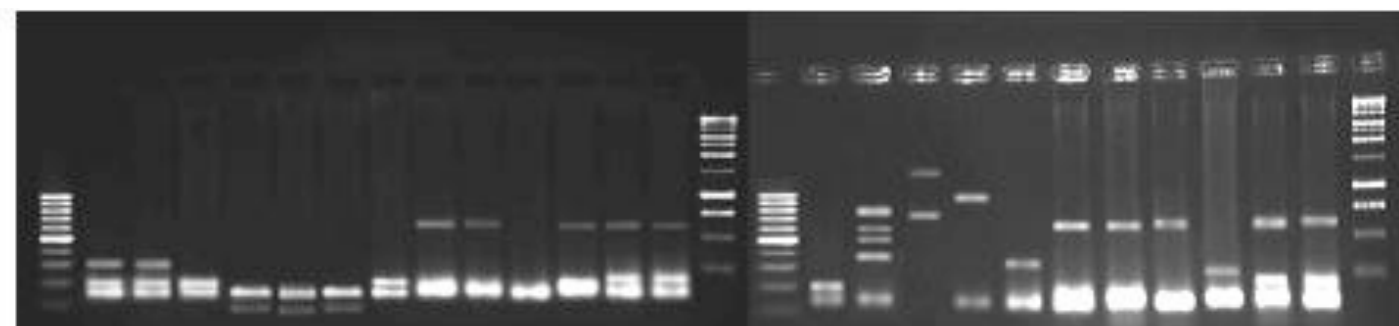

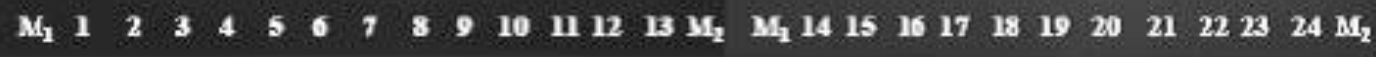

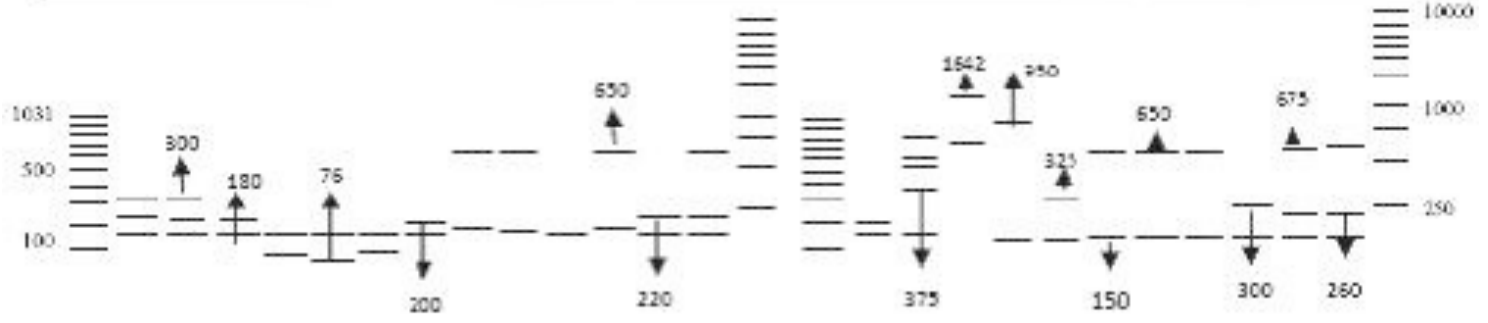

Figure 3. Electrophoregram of 24 accessions DNA amplification using SMC1047HA primers.

Gambar 3. Elektroforegram amplifikasi DNA 24 aksesi menggunakan primer mikrosatelit SMC1047HA

Remark: IS 76-202, 2. IS 76-205, 3. IK 76-149, 4. IK 76-150, 5. IK 76-153, 6. IJ 76-374, 7. IJ 76- 375, 8. IJ 76-370, 9. IJ 76-348, 10. IJ 76-396, 11. M 442-51, 12. PS-862, 13. TD 50, 14. TD 53, 15. 15 OC 18, 16. 15 OC 19, 17. IK76-36, 18. IK76-41, 19. IS 76-175, 20. IS 76-181, 21. IJ 76-412, 22. IJ 76-415, 23. X OC 55, 24. X OC 56, M1. Marker 100 bp and M2. Marker 1kb.

Keterangan: IS 76-202, 2. IS 76-205, 3. IK 76-149, 4. IK 76-150, 5. IK 76-153, 6. IJ 76-374, 7. IJ 76- 375, 8. IJ 76-370, 9. IJ 76-348, 10. IJ 76-396, 11. M 442-51, 12. PS-862, 13. TD 50, 14. TD 53, 15. 15 OC 18, 16. 15 OC 19, 17. IK76-36, 18. IK76-41, 19. IS 76-175, 20. IS 76-181, 21. IJ 76-412, 22. IJ 76-415, 23. X OC 55, 24. X OC 56, M1. Marker 100 bp and M2. Marker $1 \mathrm{~kb}$.

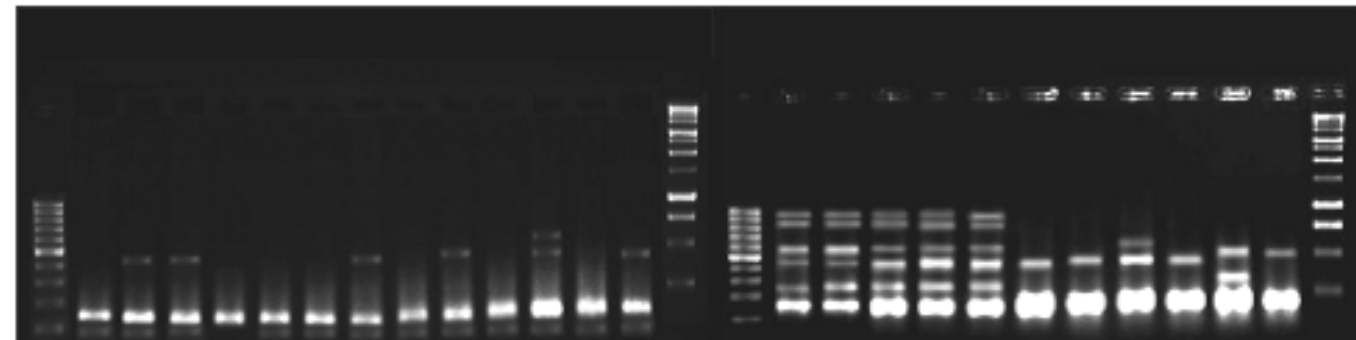

$\begin{array}{llllllllllllllllllllllllllll}M_{1} & 1 & 2 & 3 & 4 & 5 & 6 & 7 & 8 & 9 & 10 & 11 & 12 & 13 & M_{2} & M_{1} & 14 & 15 & 16 & 17 & 18 & 19 & 20 & 21 & 22 & 23 & 24 & M_{2}\end{array}$

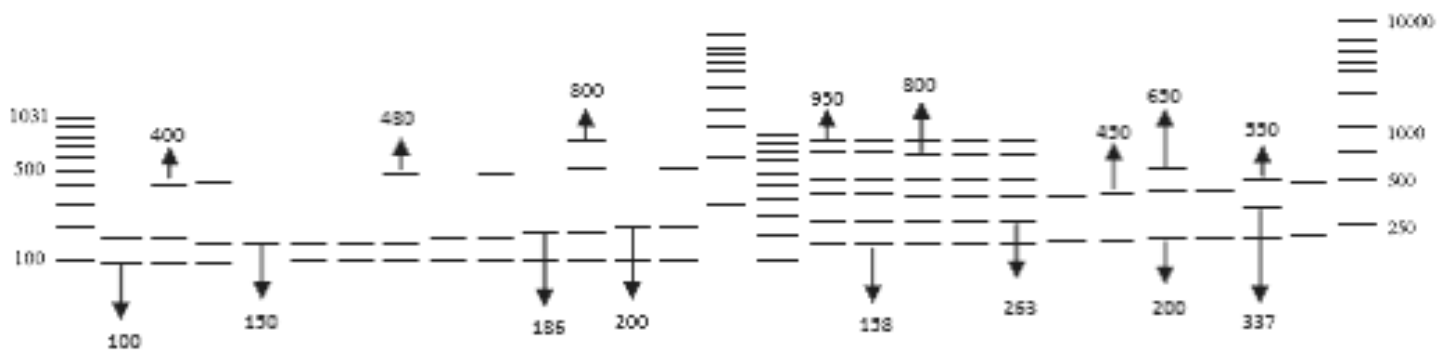

Figure 4. Electrophoregram of 24 accessions DNA amplification results using MSCA053C10 primer. Gambar 4. Elektroforegram hasil amplifikasi DNA 24 aksesi menggunakan primer MSCA053C10

Remark: IS 76-202, 2. IS 76-205, 3. IK 76-149, 4. IK 76-150, 5. IK 76-153, 6. IJ 76-374, 7. IJ 76- 375, 8. IJ 76-370, 9. IJ 76-348, 10. IJ 76-396, 11. M 442-51, 12. PS-862, 13. TD 50, 14. TD 53, 15. 15 OC 18, 16. 15 OC 19, 17. IK76-36, 18. IK76-41, 19. IS 76-175, 20. IS 76-181, 21. IJ 76-412, 22. IJ 76-415, 23. X OC 55, 24. X OC 56, M1. Marker 100 bp and M2. Marker 1kb.

Keterangan : IS 76-202, 2. IS 76-205, 3. IK 76-149, 4. IK 76-150, 5. IK 76-153, 6. IJ 76-374, 7. IJ 76- 375, 8. IJ 76-370, 9. IJ 76-348, 10. IJ 76-396, 11. M 442-51, 12. PS-862, 13. TD 50, 14. TD 53, 15. 15 OC 18, 16. 15 OC 19, 17. IK76-36, 18. IK76-41, 19. IS 76-175, 20. IS 76-181, 21. IJ 76-412, 22. IJ 76-415, 23. X OC 55, 24. X OC 56, M1. Marker 100 bp and M2. Marker $1 \mathrm{~kb}$. 


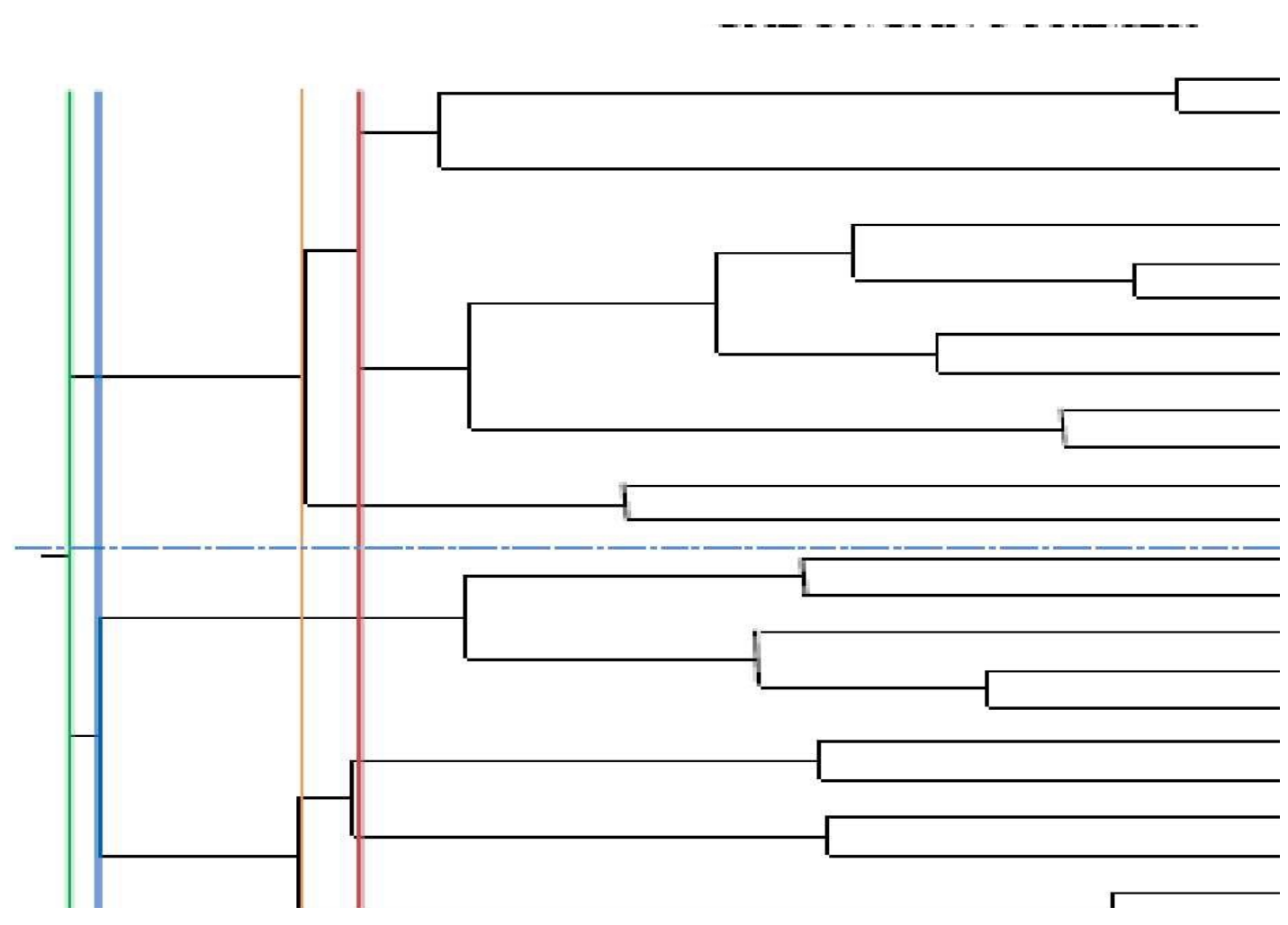

Figure 5. The genetic relationships between 24 accessions of the Saccharum complex based on three molecular markers by using the Jaccard coefficient

Gambar 5 . Hubungan kekerabatan 24 aksesi Saccharum complex berdasarkan penanda molekuler menggunakan koefisien Jaccard

The results of this study similar to the results of research conducted by Olieviera et al. (2017) to assess the genetic diversity of 26 accessions of sugarcane from the Active Germplasm Bank of the Embrapa Coastal Tablelands, using inter-simple sequence repeat (ISSR) molecular markers. Sixteen primers were used, resulting in 87 fragments with $91.13 \%$ of polymorphism. The similarity of the individuals ranged between 0.22 and 0.87 . Four distinct clusters were formed using UPGMA. Despite the large distribution of accessions in most groups, indicating great genetic diversity, these were not separated by a group of the same species in each subcluster, which common alleles could explain among different species, since they are of the same genus. Similar results were found by Raj et al. (2016) that there was a close relationship among the different species that constitute the Saccharum complex; however S. spontaneum, contributing to greater diversity.

Subcluster I.2 consisted of the S. robustum accessions. Large cluster II at a similarity value of 0.04 was divided into two subclusters, namely, subgroup II. 1 consisting of accessions of the genus Erianthus originating from Papua and subcluster II. 2 consisting of (A) accessions from $S$. barberi; (B) accession of the genus Miscanthus; and (C) accession of the Saccharum hybrid. Figure 5 shows that the grouping based on the molecular markers of the 24 accessions analyzed were grouped according to species, this is the same as the grouping at the time of conservation. The genetic similarity value for the 24 accessions was very low at around 0.20 .

As reported by Aitken et al. (2018), who analyzed the diversity of several accessions to $S$. spontaneum species from 21 different countries using molecular markers, the results of their analysis revealed that the majority of the accessions were clustered according to the country of origin. Genetic similarity ranged from 0.25 to 0.54 , with the highest diversity in accessions collected in Indonesia, followed by China, India, and Thailand, and the lowest in the Philippines. Likewise, the results of the analysis conducted by Manish et al. (2014) on 40 genotypes of Indian sugarcane using microsatellites. The molecular results obtained in the study of Manish et al. (2014) are represented and agree with the possible evolutionary course of sugarcane genotypes. The UPGMA cluster analysis of 40 genotypes in that study produced meaningful grouping based on pedigree or geographical origin of the accessions. The grouping patterns of 40 genotypes are based on their genetic similarity pattern which shows that sugarcane genotypes from the same geographical regions tend to cluster together which may resulting from a shared evolutionary pathway. 
Genetic relationship based on morphological and molecular markers

Information about the value of genetic similarity can be used as a reference to determine the value of genetic distance, phylogenetic relationships, and the level of genetic diversity. The value of genetic similarity is directly proportional to the genetic relationship but inversely proportional to the value of genetic distance or dissimilarity. The greater the value of similarity between two accessions, the greater the genetic relationship (closer), but conversely, the value of the genetic distance is small.

The markers used in this study were morphological and microsatellite markers, each of which had advantages and disadvantages. The use of these two markers in this study was to support and complement the analysis of the grouping and phylogenetic relationship of 24 accessions of the Saccharum complex. The data derived from morphological and molecular character were qualitative, so they were transformed into binary data before making the dendrogram of genetic relationship.

The dendrogram of the genetic relationship of the morphological characters was constructed based on the Simple Matching (SM) coefficient similarity (Figure 1). The dendrogram shows that the 24 accessions of the Saccharum complex including the genus Erianthus and Saccharum have a close relationship of 0.5714-0.9683 with a genetic distance of $0.0317-0.4286$. This low diversity was due to the 24 accessions analyzed with similar morphological features from the 37 characters observed. Therefore, grouping based on morphological markers was considered insufficient to verify the classification of germplasm collections managed by ISRI, so that molecular markers were still needed to support the validity of existing groupings.

On the other hand, the value of genetic similarity based on molecular markers between 24 accessions ranged from 0.000 to 0.889 (Figure 5 ). Duplication (similarity value $=1.00$ ) was not found among the 24 clones tested. A high genetic similarity was observed in some accessions because the accessions were included in groups of the same species.

Qualitative data on the characterization of molecular markers were used to construct a dendrogram of genetic relationship with Jaccard's similarity coefficient. The Jaccard's coefficient is appropriate for molecular markers because Jaccard's coefficient only considers the characters or bands that appeared (present) as a contributing factor to individual similarity and ignores zero (0) or absence. As in the research of Cordeiro et al. (2003), Widyasari et al. (2008) and Pocovi et al. (2020) used Jaccard's coefficient to analyze the genetic diversity of sugarcane which based on molecular markers.

The grouping based on the molecular data shows that of the 24 accessions evaluated, each accession was grouped according to its species. This means that based on molecular markers, the grouping of ISRI's sugarcane germplasm collections was still in accordance with the grouping at the conservation time.

The results of this study indicate that there are differences in the value of genetic similarity in the 24 accessions analyzed based on the markers used. According to morphological markers, the value of genetic similarity was higher than the value of genetic similarity based on molecular markers. The morphological markers caused the difference because the observed morphological characters were 37 characters with 126 descriptions, while the molecular markers, using three microsatellite primers, could produce 90 DNA bands. In addition, descriptions of morphological characters that were equally absent were considered the same variable, even though their morphological characters were different. It was a cause of increased genetic similarity value when the genetic relationship was analyzed using morphological markers.

Another factor influencing these differences is the difference in the similarity coefficient used on morphological and molecular markers in evaluating the genetic relationship of those 24 accessions. Morphological markers used the Simple Matching similarity coefficient, which involved the absent value $(d, 0-0)$. In contrast, the molecular markers used the Jaccard's similarity coefficient, which only involved the present values $(\mathrm{a}, \mathrm{b}, \mathrm{c})$.

However, the two markers gave the same grouping results. This can be seen in the accessions of S. officinarum, TD50 with TD53 into one group; S. spontaneum, IK76-36 and IK76-41 in one group; S. sinense, $15 \mathrm{OC} 18$ and $15 \mathrm{OC} 19$ in one group; Erianthus clones originating from Irian Jaya (IJ) also form a separate subgroup of Erianthus originating from Kalimantan and Sulawesi. Meanwhile, the classification of several accessions was different based on morphological and molecular markers. It was shown in the accessions of $S$. barberi, S. robustum, and Saccharum hybrid. The fact that grouping based on molecular markers is not exactly the same as a grouping based on morphological markers is also found in Pocovi et al. (2020).

Regarding the accuracy of genetic relationships, some researchers argue that molecular markers are considered to be more accurate in phylogenetic analysis than morphological markers. This is because molecular markers analyze individuals at the DNA level, whereas morphological markers had several drawbacks that could affect the accuracy of the data. Bagali et al. (2010) stated that morphological markers are markers that recognize a character according to their natural appearance based on the observer's view (subjectivity). In addition, Martinez et al. (2003) reported that morphological markers were relatively insignificant and inefficient for accuracy in 
distinguishing closely related genotypes and analyzing their genetic similarities when compared to DNA fingerprinting techniques. However, morphological markers are helpful at the beginning or early stage, fast, simple, and inexpensive to identify varieties, and could be used as a general approach to measuring genetic diversity between cultivars of different phenotypes. Karuri et al. (2010) stated that it was necessary to combine them with genetic-based markers due to limitations in morphological markers.

\section{Conclusion}

The grouping of the 24 accessions of the ISRI's Saccharum complex germplasm collection was based on molecular markers according to the grouping at the $\mathrm{t}$ conservation time. Meanwhile, the grouping based on morphological markers in several accessions did not match the classification at the conservation time. This occurs in accessions of the Saccharum robustum, Saccharum barberi, Saccharum hybrid, and the genus Miscanthus. Based on molecular markers, the 24 accessions of the Saccharum complex had a high degree of diversity. These clones can be used as a combination of crossing parents to produce new superior sugarcane varieties.

\section{References}

Aitken K, Li J, Piperidis G, Qing C, Yuanhong F \& Jackson P (2018) Worldwide genetic diversity of the wild species Saccharum spontaneum and level of diversity captured within sugarcane breeding programs. Crop Sci 58(1), 218-29.

Ali A, Yong bao-Pan, Qin-Nan Wang, Jin-Da Wang, Jun-Le Chen \& San-Ji Gao. (2019). Genetic diversity and population structure analysis of Saccharum and Erianthus genera using microsatellite markers. Sci Rep 9, 395.

Alix K, F Baurens, F Paulet, J Glaszmann \& AD Hont (1998). Isolation and characterization of a satellite DNA family in the Saccharum complex. Genome 864 (Arceneaux 1965), 854 864.

Alwala S, A Suman, JA Arro, JC Veremis, \& CA Kimbeng (2006). Target Region Amplification Polymorphism (TRAP) for assessing genetic diversity in sugarcane germplasm collections. Crop Sci (44), 448-455. doi: $10.2135 /$ cropsci2005.0274.

Amalraj VA \& N Balasundaram (2006). On the taxonomy of the members of Saccharum complex. Genetic Res Crop Evol (53), 35-41.

Bagali PG, PDAH Prabhu, K Raghavendra, PG Bagali \& JS Vadivelu (2010). Application of molecular markers in plant tissue culture. $\mathrm{J} \mathrm{Mol}$ Biol Biotechnol 18(1), 85-87.

Birchler JA \& NC Riddle (2014). In search of the molecular basis of heterosis. Plant Cell 15,
2263-2239. doi: 10.1105/tpc. 151030 .

Burnquist WL, ME Sorelles \& S Tanksley (1995). Characterisations of genetic variability in Saccharum germplasm by means of restricted fragment length polymorphism (RFLP) analysis. Proc ISSCT 21,355-356.

Caroll BJ \& MD Curtis (1996). Plant biotechnology research and prospects for sugarcane, including transformation. Proc ISSCT 22,5-14.

Cordeiro GM, YB Pan \& RJ Henry ( 2003). Sugarcane microsatellites for the assessment of genetic diversity in sugarcane germplasm. Plant Sci 165,181-189.

Costa MLM Da, Amorim LLB, Onofre AVC, Melo LJOT de, Oliveira MBM de, \& Carvalho $\mathrm{R}$ (2011). Assessment of genetic diversity in contrasting sugarcane varieties using InterSimple Sequence Repeat (ISSR) markers. Am J Plant Sci 2, 425 - 432.

D’Hont A \& JE Glaszmann (2001). Sugarcane genome analysis with molecular markers: A first decade of research. Proc ISSCT 24, 556-559.

Devarumath BM, Kalwade SB, Kawar PG \& Sushir KV (2012). Assesment of genetic diversity in sugarcane germoplasm using ISSR and SSR markers. Sugar Tech 14, 334-344. https://doi.org/10.1007/s12355-012-0168-7

Diederichs GW, MA Mandegari, S Farzad, \& JF Görgens (2016). Technology Technoeconomic comparison of biojet fuel production from lignocellulose, vegetable oil and sugar cane juice. Bioresour Technol 216, 331-339. doi: 10.1016/j.biortech.2016.05.090.

dos Santos JM, Duarte Filho LSC, Soriano ML, da Silva PP, Nascimento VX \& de Souza Barbosa $\mathrm{GV}$ (2012). Genetic diversity of the main progenitors of sugarcane from the RIDESA germplasm bank using SSR markers. Elsevier $40,145-150$.

FAO (2019). Country report on the state of plant genetic resources for food and agriculture. Indonesia.

Hameed U, Y-B Pan, K Muhammad, S Afghan \& J Iqbal (2012). Use of simple sequence repeat markers for DNA fingerprinting and diversity analysis of sugarcane (Saccharum spp) cultivars resistant and susceptible to red rot. Genet Mol Res 11 (2), 1195-1204.

Indah JN, S Liliek \& SA Noor (2008). Cucumber (Cucumis sativus L.) relationship analysis using RAPD-PCR and isozyme methods. Biodiversity 9, 99-102. doi: 10.13057/biodiv/d090205.

ISRI (1997). One hundred and ten years of 
service. Indonesian Sugar Research Institute. Pasuruan.

Karuri H, EM Ateka, R Amata, AB Nyende, AWT Muigai, E Mwasame \& ST Gichuki, (2010). Diversity among kenyan sweet potato genotypes using morphological and SSR Markers. J Agric Biol 12, 33-38.

Khan FA, FM Azhar \& S Rauf (2009). Genetic diversity of Saccharum officinarum accessions in Pakistan as revealed by random amplified polymorphic DNA. Genet Mol Res 8(4), 13761382.

Lamadji S (1994). Pelestarian plasma nutfah tebu. Gula Indonesia XIX/1:33-37.

Liu X, Li X, Liu H, Xu C, Lin X, Li C \& Z Deng. (2016). Phylogenetic analysis of different ploidy Saccharum spontaneum based on rDNA-ITS sequences. PLoS ONE 11(3), e0151524.

https://doi.org/10.1371/journal.pone.0151524

Lopes AD, CA Scapim, M De Fátima, S Machado, \& CA Mangolin (2015). Genetic diversity assessed by microsatellite markers in sweet corn cultivars. Sci Agric 72(6), 513-519. doi: 10.1590/0103-9016-2014-0307.

Manechini JRV, JB da Costa, BT Pereira, LA Carlini-Garcia, MA Xavier, MGdA Landell, \& LR Pinto (2018). Unraveling the genetic structure of Brazilian commercial sugarcane cultivars through microsatellite markers. PLoS ONE 13(4), e0195623. https://doi.org/ 10.1371/journal.pone.0195623

Manish DS, Upma Dobha, Prashant Singh, Shailender Kumar, AK Gaur1, SP Singh, AS Jeena, Eapen P Koshy \& S Kumar (2014). Assessment of genetic diversity among sugarcane cultivars using novel microsatellite markers. African J Biotechnol 13(13), 14441451.

Mantel N (1967). The detection of disease clustering and a generalized regression approach. Cancer Res 27(2), 209-20.

Marconi TG, Costa EA, Miranda HR, Mancini MC, Cardoso-Silva CB \& Oliveira KM (2011). Functional markers for gene mapping and genetic diversity studies in sugarcane. $B M C$ Res Notes. doi: 10.1186/1756-0500-4-264.

Martinez L, P Cavagnaro, N Scientific \& R Masuelli (2003). Evaluation of diversity among Argentine grapevine (Vitis vinifera L.) varieties using morphological data and AFLP markers protein interactions in enzymatic processes in textiles. J Biotechnol 6, doi: 10.2225/vol6issue 3-fulltext-11.

Medeiros C, Balsalobre TWA \& Carneiro MS (2020). Molecular diversity and genetic structure of Saccharum complex accessions.
PLoS ONE 15(5): e0233211. https : //doi.org/10.1371/journal.pone.0233211

Mirzawan PDN, WB Widyasari \& G Sukarso (2014). Sumberdaya genetik tebu: status dan pemanfaatannya. Badan Penelitian dan Pengembangan Pertanian. Kementrian Pertanian. Jakarta. p. 122-148.

Oliveira LAR, CA Machado, MN Cardoso, ACA Oliveira, AL Amaral, ARC Rabbani, AVC Silva \& AS Ledo (2017). Genetic diversity of Saccharum complex using ISSR markers. Genet Mol Res 16 (3), doi: http://dx.doi.org/10.4238/gmr16039788

Pan YB, Gm Cordeiro, EP Richard \& RJ Henry (2003). Molecular genotyping of sugarcane clones with microsatellite DNA markers. Maydica (48),319-329

Pan YB (2010). Databasing molecular identities of sugarcane (Saccharum spp.) clones constructed with microsatellite (SSR) DNA markers. Am J Plant Sci 1, 87-94.

Pandey A, Mishra RK, Mishra S, Singh YP \& S Pathak (2011). Assessment of genetic diversity among sugarcane cultivars (Saccharum officinarum L.) using simple sequence repeats markers. J Biol Sci 11, 105-111. https://doi.org/10.3844/ojbsci.2011.105.111

Parida S, S Kalia, G Hemaprabha \& S Athiappan (2008). Informative genomic microsatellite markers for efficient genotyping applications in sugarcane. Theor Appl Genet. doi: 10.1007/s00122-008-0902-4.

Pocovi IM, NoG Collavino, Ángela Gutiérrez, Gisel Taboada, Verónica Castillo, Romina Delgado, Jorge A \& Mariotti (2020). Molecular versus morphological markers to describe variability in sugar cane (Saccharum officinarum) for germplasm management and conservation. Rev FCA UNCUYO 52(1), 40-60.

Raj P, Selvi A, Prathima PT \& Nair NV (2016). Analysis of genetic diversity of Saccharum complex using chloroplast microsatellite markers. Sugar Tech 18, 141-148. https:/doi.org/10.1007/s12355-015-0382-1

Rao VP, Singh S, Chaudhary R, Sharma MK, SR Sengar, UM Singh \& V Sharma (2016). Genetic variability in sugarcane (Saccharum spp. Hybrid) genotypes through inter simple sequence repeats (ISSR) markers. J Appl Nat Sci 8, 1404-1409

Saghai-Maroof MA, SKM Jorgensen \& Allard (1984). Ribosomal DNA spacer-length polymorphisms in barley: Mendelian inheritance, chromosomal location, and population dynamics. Proc Natl Acad Sci USA, p. $8014-8018$

Sastrowijono S (1996). Cara mengenal klon klon 
tebu secara morfologis. Indonesian Sugarcane Research Institute, Pasuruan.

Schenk M, MW Crepeau, PH Moore, WK, Q Yu, \& R Ming (2004). Genetic diversity and relationships in native Hawaiian Saccharum officinarum Sugarcane. J Hered 95(4), 327-331. doi: 10.1093/jhered/esh052.

Silva DCD, Filho L, Santos J dos, Barbosa G de S, Almeida C \& Sérgio L (2012). DNA fingerprinting based on simple sequence repeat (SSR) markers in sugarcane clones from the breeding program RIDESA. African $J$ Biotechnol 11, 4722-4728.

Singh RB, B Singh \& RK Singh (2018). Evaluation of genetic diversity in Saccharum species clones and commercial varieties employing molecular (SSR) and physiological markers. Indian J Plant Genet Res 31(1),17-26.

Sneath PH \& RR Sokal (1973). Numerical Taxonomy: the principles and practice of numerical classification. San Francisco: Freeman.

Todd J, Wang J, Glaz B, Sood S, Ayala-Silva T, Nayak SN, NC Glynn, OA Gutierrez, DN Kuhn, M Tahir \& JC Comstock (2014). Phenotypic characterization of the Miami World Collection of sugarcane (Saccharum spp.) and related grasses for selecting a representative core. Genet Resour Crop Ev 61(8),1581-96.

Ullah SMS, Hossain MA, Hossain MM, Barman S, MH Sohag \& SH Prodhan (2013). Genetic diversity analysis of chewing sugarcane (Saccharum officinarum L.) varieties by using RAPD markers. J Biosci Biotechnol 2, 145-150.

Vieira MLC, L Santini, AL Diniz \& CF Munhoz (2016). Microsatellite markers: What they mean and why they are so useful. Genet Mol Biol 39, 312-328. pmid:27561112

Vieira MLC, Almeida CB, Oliveira CA, Tacuatiá LO, Munhoz CF \& Cauz-Santos L (2018). Revisiting meiosis in sugarcane: Chromosomal irregularities and the prevalence of bivalent configurations. Front Genet 14 (9), 213. pmid:29963076

Widyasari WB, Nur Basuki, \& Eka Sugiyarta (2008). Identifikasi keragaman genetik koleksi tebu asli ( $S$. officinarum) asal Indonesia menggunakan penanda molekuler mikrosatelit. Majalah Penelitian Gula 44(2), 73-95

Zhang J, Zhang X, Tang H, Zhang Q, Hua X, Ma $X$, et al (2018). Allele-defined genome of the autopolyploid sugarcane Saccharum spontaneum L. (2018). Nature genet. 50(11),1565-73. pmid:3029 